\title{
The influence of capital origin \\ on Brazilian foreign trade patterns
}

\author{
Célio Hiratuka and Fernanda De Negri
}

$\Gamma_{h}$

is article aims to determine whether the geographical pattern of the external trade of foreign-owned enterprises in Brazil differs from that of domestic enterprises and whether, in the case of foreign enterprises, the region of origin of their capital is an important factor in determining that pattern, both in terms of the origin and destination of their imports and exports and with regard to the technological content of the pattern. The methodology employed was panel analysis, applied to a representative set of enterprises, using trade data broken down by region for 1989, 1997 and 2000.

Celio Hiratuka

Research Fellow of the Center for Industrial Economics and Technology (NEIT), Institute of Economics (IE), State University of Campinas

$\rightarrow$ celio@eco.unicamp.br

Fernanda De Negri Research Fellow, NEIT/IDE, State University of Campinas - fdenegri@eco.unicamp.br 
I

\section{Introduction}

Foreign enterprises have always had a large share in the Brazilian economy. This was the result of economic policies which for many years promoted the internationalization of the national productive system as a means of economic development and incorporation into the world market. Arguments such as the need for foreign savings, greater technological capacity and the foreign enterprises' better position in foreign trade were often adduced to justify the role of foreign capital in the country. The presence of foreign enterprises, especially in "heavy" industry, was indeed a decisive factor in Brazil's industrialization process, because their activities complemented those of the private-sector and State enterprises responsible for the "light" sectors of industry and the infrastructural sectors, respectively.

The growing internationalization of the Brazilian economy, as a result of a fresh wave of foreign direct investment (FDI) in the 1990s, revived the debate on the role of foreign enterprises. In recent years there have also been some changes which are extremely important in terms of this debate and in terms of the effects of internationalization on the performance of the national productive sector.

Firstly, there is the process of trade and financial liberalization in the early 1990 s, which increased the coefficients of exports and imports and, in some respects, made the Brazilian economy more vulnerable to changes in globalized financial markets. Secondly, there are the regional trade agreements such as MERCOSUR and the negotiations for the establishment of a Free Trade Area of the Americas (FTAA) and an agreement between MERCOSUR and the European Union, which are likely to have significant effects on the foreign trade performance of the country in the coming years.

It was in this context that many of the recent studies on the role of foreign enterprises sought to analyze their effects on trade flows. In particular, the greater openness of the economy seems to have led some analysts to believe that the role of foreign enterprises in

$\square$ The authors wish to acknowledge the comments made by an anonymous referee of the CEPAL Review and by colleagues from the Núcleo de Economía Industrial y Technología.
Brazil's foreign trade would become more significant and beneficial for the country. Various studies also sought to compare the trade performance of foreign enterprises with that of domestic firms. In general, the results obtained showed that there were differences between the performance of the two types of enterprises: the foreign enterprises showed greater integration with the exterior, although this was more pronounced in the case of imports than of exports.

The aim of this study, apart from identifying the trading differences between domestic and foreign enterprises, is to go more deeply into the possible causes of these differences. One of these causes, which has far-reaching implications in view of the possible signing of trade agreements with the FTAA and the European Union, has to do with the influence of the region of origin of the capital of foreign enterprises on the patterns of origin and destination and technological content of Brazil's foreign trade. This article therefore seeks to appraise the regional trading pattern of foreign enterprises in Brazil as a function of the regions of origin of their capital and their differences with domestic enterprises and foreign enterprises in other regions.

This article is divided into six sections. The following section, section II, briefly addresses the relations between foreign direct investment (FDI), the activities of transnational corporations and trade flows in the recent past. Section III summarizes the main results of the studies on foreign enterprises and trade in Brazil made during the 1990s. Section IV contains an econometric analysis on a panel of 165 foreign and domestic industrial enterprises on the basis of data for 1989, 1997 and 2000 with a view to identifying regional trade differences between the enterprises according to their nationality and the region of origin of their capital. Section V seeks to determine if the technological density of foreign enterprises' trade influences their regional trade pattern and, more specifically, how much it influences their trade flows with their region of origin. Finally, section VI presents the main conclusions of the study, together with some inferences that may be drawn in terms of economic and trade policy. 


\section{The effects of foreign direct investment and transnational corporations on international trade}

The rapid growth of trade and FDI flows has been given a great deal of attention recently in international economic studies. As may be seen from table 1, both these flows, but particularly those of FDI, have grown on average considerably faster than world GDP over the last 20 years.

It may also be seen from that table that a counterpart to the faster growth of FDI flows than world trade and the world product was an increase in the importance of transnational corporations in the global economy. The total sales of the subsidiaries of those enterprises came to US\$ 15.6 billion in the year 2000 , which represents added value of some US\$ 3.1 billion. The average annual growth rate between 1982 and 2000 was $8.9 \%$ for sales and $8 \%$ for value added, while the share of the subsidiaries of transnational corporations in the generation of world GDP rose from $5.6 \%$ to $10.1 \%$ over the same period. It should be noted that these figures do not include the product generated by the operations of the parent firms in their home countries, but only that of their subsidiaries abroad, thus under-estimating the total share of transnational corporations in the generation of world wealth.

TABLE 1

Economic indicators of world as a whole and of subsidiaries of transnational corporations, 1982, 1990 and 2000

(Billions of 2000 dollars)

\begin{tabular}{|c|c|c|c|c|}
\hline & 1982 & 1990 & 2000 & $\begin{array}{c}\text { Variation between } \\
1982 \text { and } 2000 \\
\text { (annual average, \%) }\end{array}$ \\
\hline \multicolumn{5}{|l|}{ World data } \\
\hline FDI flows & 77 & 239 & 1271 & 16.9 \\
\hline World GDP & 14086 & 24518 & 31363 & 4.5 \\
\hline Exports & 2492 & 3977 & 6338 & 5.3 \\
\hline \multicolumn{5}{|l|}{ Data for subsidiaries of transnational corporations ${ }^{\mathrm{a}}$} \\
\hline Sales & 3373 & 6256 & 15680 & 8.9 \\
\hline Assets & 2601 & 6804 & 21102 & 12.3 \\
\hline Product & 789 & 1625 & 3167 & 8.0 \\
\hline Exports & 889 & 1335 & 3572 & 8.0 \\
\hline Product of transnational subsidiaries/world GDP (\%) & 5.6 & 6.6 & 10.1 & \\
\hline Exports of transnational subsidiaries/world exports (\%) & 35.7 & 33.5 & 56.4 & \\
\hline
\end{tabular}

Source: United Nations Conference on Trade and Development (UNCTAD).

a For 2000: UNCTAD estimate.

It is also important to note that the share of the transnational subsidiaries in the total GDP of the industrial sector is considerably greater than those of the primary sector and of commerce and services. According to calculations made by Lipsey (1998) in 1990 the internationalized product in industry at the world level, that is to say, the proportion of a country's product controlled by enterprises based in other countries, represented $16 \%$ of world industrial GDP, and this percentage must have increased still further in recent years.

As for trade flows, in 1999 the total exports of transnational subsidiaries were estimated to amount to US\$ 3.5 billions, representing nearly $56 \%$ of total world exports, compared with $35.7 \%$ in 1982 . The share of the parent firms is not included in this figure in this case either, thus under-estimating once more the incidence of transnational corporations in total 
exports. Even so, these data clearly show that FDI and international trade are interdependent phenomena, and also that an increasing share of trade flows is under the control of transnationals. According to estimates of the United Nations Conference on Trade and Development (UNCTAD, 1995), almost two-thirds of world trade involves a transnational corporation in some way, and nearly half of this figure corresponds to intra-firm trade. In other words, trade within transnational corporations represents almost a third of total world trade.

This phenomenon has given rise to a large number of theoretical and practical studies which seek to identify the relations between FDI flows, the activities of transnational corporations and trade flows by treating these variables in a more integrated manner.

The effect of the activities of transnational firms on trade flows was neglected for a long time in trade theory. The formal expression of Heckscher-Olin-type comparative advantage models included among its various prior assumptions the hypothesis that the factors of production were immovable and could hence only be analysed in the country where they were located. Furthermore, the idea of the enterprise inherent in the model was that of a production unit manufacturing only one product in a single plant, in an environment where there was perfect competition in all markets. This excluded in advance the possibility of the existence of transnational corporations, both because it would be impossible for the enterprises of one country to use the factors of production of another or for a foreign-owned firm to build up any kind of advantage over domestic firms in producing for the local market, in view of the hypothesis of perfect competition.

Although trade theories which exclude the transnational corporations are still sometimes used as explanatory models, the recognition that the activities of transnational corporations influence trade flows and patterns has stimulated the preparation of studies which seek to incorporate this aspect in equilibrium models based on the new international trade theories.

Basically, two main lines of argument can be identified to explain the emergence of transnational corporations in the new trade patterns. The first line, expounded in particular by Helpman (1984) and Helpman and Krugman (1985), seeks to explain the vertical investments of such corporations, which have the characteristic of carrying out different stages in the production chain in different countries, taking advantage of the disparities between the proportions of production factors in each country. In these models, the firms are assumed to concentrate activities relating to more capital-intensive business functions in the country with the biggest relative endowment of this resource, exporting those services a production unit located in the country with the best endowment of labour, which would then export the end-product. International investment logic is therefore assumed to be connected with the possibility of separating the various stages of production to take advantage of the differences in factor costs, thus giving rise to intra-firm trade in business functions and end-products.

The second line of argument, developed by authors such as Brainard (1993), Markusen (1995) and Markusen and Venables (1998), analyses horizontal investments, namely, the transnational establishment of plants with similar product lines in countries which are similar in terms of market size, income, and endowment of factors of production. Horizontal investment is assumed to take place when the transport costs and prices of a plant are high and its economies of scale at the plant level are small compared with the economies of scale at the level of the firm as a whole. These patterns would explain the growing cross-flows of FDI among developed countries. The equilibrium situation in which the transnational corporations prevail would result in the predominance of direct sales in the countries where the subsidiaries are located, to the detriment of exports.

Some studies ${ }^{1}$ which depart from the equilibrium models and are closer to the literature on the operations of transnational corporations state that the interaction between the increase in competition at the world level, the deregulation and/or liberalization of markets and the spread of information technologies in recent years have caused transnational corporations to seek something more than just the exploitation of factor cost differences or new markets.

FDI flows have also come to be directed towards the rationalization of the already established structure, in order to take advantages of the economies of scale available through the unified management of geographically dispersed production activities and the acquisition of assets that promote training for competition and help to attain strategic goals in global and regional markets.

Whereas previously the chain of value of enterprises was reproduced almost in full in each subsidiary, the expansion and rationalization of that struc-

\footnotetext{
1 Such as those by Chesnais (1996), Dunning (1993) and UNCTAD (2002a and 2002b).
} 
ture has resulted in a more fragmented chain in which the subsidiaries carry out activities and functions that form part of a much more complex international division of labour. The decision to assign a production or business activity to a given place has come to be based on the expectation that this will make a contribution to the global performance of the transnational corporations. Subsidiaries have begun to specialize in particular areas and to provide components or a particular line of products to the rest of the network, either within a region or worldwide, even taking on business functions for the line in question, such as organizing purchases and research and development activities (UNCTAD, 1995).

As the accumulation potential of transnational corporations has come to depend on the way they organize, coordinate and globally integrate their various activities, there has been an increase in the flows of information and resources between the parent firm and its subsidiaries, as well as among the various subsidiaries themselves. These flows involve everything from financial to technological resources, including all types of information connected with business management. The most visible aspect of this integration is the flow of products. The greater share of transnational corporations in trade flows, as shown in table 1, reflects not only the quantitative increase in the internationalization of big corporations, but also changes in their way of acting and new objectives of FDI flows.

The already noted increase in intra-firm trade is also directly related with the expansion and integration of the activities of transnational corporations at the world level. As noted by Anderson and Fredriksson (2000), intra-firm trade has increased in recent years not only with respect to intermediate products, but also end-products.

Consequently, any analysis of trade flows and patterns must take into account the fact that a growing proportion of those flows corresponds to internal operations of the transnational corporations or subcontracting arrangements, and therefore does not involve pure market transactions.

In the present context, the reorganization of world production and marketing chains, which is necessarily accompanied by structural changes in the trade patterns of the countries of origin and destination of FDI, forms part of the inherent logic of the transnational corporations. According to Mortimore, Vergara and Katz (2001) and UNCTAD (2002a), one of the main factors which has conditioned the insertion of the developing countries in international trade flows, especially of more technology-intensive products, has been their participation in the internationally integrated production systems organized by the big transnational corporations.

In the next section we will analyze the studies which have been made with a view to establishing the effects of the activities of the transnational corporations on Brazil's external trade in recent years.

\section{III \\ Transnational firms and Brazil's external trade in the 1990s}

FDI flows into the Brazilian economy were quite low throughout the 1980s, but they increased in the 1990s, and especially during the second half of that decade. Between 1990 and 1995 the average inflow was US\$ 2 billion per year, and this level rose steadily up to the year 2000. Since then, the investment inflow has shown a downward trend, but it still remains quite high. Brazil's share in both world FDI flows and in the total amount received by developing countries was also higher than at the beginning of the decade in relative terms (table 2). 
TABLE 2

World, developing countries and Brazil: Foreign direct investment flows received (Millions of dollars)

\begin{tabular}{|c|c|c|c|c|c|c|c|}
\hline Countries and regions & $1990-1995^{\mathrm{a}}$ & 1996 & 1997 & 1998 & 1999 & 2000 & 2001 \\
\hline World & 225321 & 386140 & 478082 & 694457 & 1088263 & 1491934 & 735146 \\
\hline Developing countries & 74288 & 152685 & 191022 & 187611 & 225140 & 237894 & 204801 \\
\hline Brazil & 2000 & 10792 & 18993 & 28856 & 28578 & 32779 & 22457 \\
\hline Brazil/world & 0.9 & 2.8 & 4.0 & 4.2 & 2.6 & 2.2 & 3.1 \\
\hline Brazil/developing countries & 2.7 & 7.1 & 9.9 & 15.4 & 12.7 & 13.8 & 11.0 \\
\hline
\end{tabular}

Source: Prepared by the authors on the basis of data from the Central Bank of Brazil, ECLAC and UNCTAD.

a Annual average.

As a counterpart to the high levels of FDI inflows, there was also an increase in the importance of foreign-owned firms in Brazil's production and foreign trade structures. According to data on the 500 biggest private firms in the country, in 1989 foreignowned firms accounted for $30 \%$ of the number of firms and $41 \%$ of sales, and by the year 2000 those figures had risen to $46 \%$ and 56\%, respectively (Laplane and Sarti, 2002).

As the importance of foreign firms increased, the effects of their activities on the industrial structure of Brazil became the subject of renewed study, especially as regards trade flows.

Various authors have analyzed the trade performance of foreign-owned firms and have identified the differences with the trade patterns of domestic firms, using various different data bases and methodologies.

Moreira (1999), for example, worked with data on the income tax paid by legal persons in 1997, covering almost 26,000 firms, and observed that in a particular sector and size range of firms the exports of foreign firms were $179 \%$ higher on average than those of domestic firms, while their imports were $316 \%$ higher on average.

Using the same data base, Pinheiro and Moreira (2000) found that foreign-owned firms were more likely to export and that the expected value of their exports was 32\% higher than that of domestic firms. In the same study it was also noted that as the size of the firms increased, the difference between the exports of foreign-owned and domestic firms grew smaller. The model also included other variables, such as total income, intensity of capital and labour use, average wages and qualifications of the workers, concentration, and use of the installed capacity of the firms' sectors of activity. In this study, the authors did not address the differences between the two groups of firms as regards imports.

On the basis of data on the 500 biggest firms in Brazil, Chudnovsky and López (2002) carried out another exercise to identify the differences in the trade performance of domestic and foreign-owned firms. In that study, the authors found an increase in the import coefficients of foreign firms in Brazil in the 19922000 period and a small decrease in their export coefficients. Using statistical hypothesis tests in which they took account of the sector and size of the firm, they found that in 1992 there were no significant differences between the trade coefficients of foreign and domestic firms. In 1997 and 2000, however, although there were no major disparities between export coefficients, the differences between the firms' import coefficients were indeed significant.

De Negri (2003), whose study was based on micro-data from the annual industrial surveys covering almost 54,000 firms in the period from 1996 to 2000 , made a panel data analysis and also found a discrepancy in the trade behaviour of foreign and domestic firms. Once more, the difference in favour of the foreign firms was much greater in the case of imports than of exports. The results of the random effects model, which included such factors as size, productivity, skill levels of the labour force, and differences in the product and sector of activity, indicated that foreign firms exported $70 \%$ and imported $290 \%$ more than domestic companies.

In short, the studies show that orientation towards the exterior is greater among foreign-owned firms than among domestic ones, especially in the case of imports. The contrast is not so marked for exports, especially in the case of large firms.

As well as this difference in trade performance, 
another important aspect of the effects of the activities of foreign-owned firms concerns the origin and destination of trade flows. This aspect deserves to be analyzed more fully, since it has important implications for the debate on the consequences of the integration agreements currently being negotiated by Brazil. As noted by Baumann and Carneiro (2002), taking into account the capital origin and impact of transnational firms can have important implications for studies which seek to analyze the effects of integration processes but assume that transactions only take place between totally independent agents.

The study by Laplane and others (2001), which was based on a sample of 100 large foreign-owned firms in 1997, finds that these firms concentrated nearly $40 \%$ of their external sales in the countries of MERCOSUR and the Latin American Integration Association (ALADI), while their sales to more developed regions were considerably smaller: $16.6 \%$ to the North American Free Trade Area (NAFTA) and $18.5 \%$ to the European Union. On the other hand, their imports came mainly from the more developed regions (27.7\% from North America and 36\% from the European Union). The authors relate this pattern with the role played by the Brazilian subsidiaries in the strategies of their parent firms, which conditioned intra-firm trade and favoured the importation of inputs, components and final products (especially those of greatest technological density) from the parent firm or from other subsidiaries in more developed regions, while giving priority attention to the domestic market and exports to MERCOSUR and ALADI.

The analysis by Pinheiro and Moreira (2000) reproduces the estimates given by the model referred to earlier for different regions and notes that the greater probability of exporting displayed by foreignowned firms compared with domestic ones is maintained in all markets. The exports of both types of firms are directed primarily to Latin America, in second place to the other industrialized countries, except for the United States and Canada, and in third place to the latter two countries.

The study by Baumann and Carneiro (2002) aims to make a more explicit analysis of the influence of intra-firm trade and to find out to what extent the geographical concentration of exports is related with the country of origin of the transnational firms operating in Brazil. In view of the lack of detailed information on the level of intra-firm trade in that country, the authors resort to the hypothesis proposed by Baumann (1993) that, for a given transnational firm with a given country of origin, the transactions carried out with that country will be mainly with the parent firm or through marketing channels organized by that firm. Although it is possible that some transactions with the country of origin will not be of an intra-firm nature, the approximation used by these authors is the best available in view of the limitations of the available data.

Using a probit model, Baumann and Carneiro seek to identify the factors which explain the increase in exports between 1995 and 2000 in a set of 43 firms. Apart from the degree of openness of the firm or the variations in its sales, it is noteworthy that the exports were mainly to the MERCOSUR countries, NAFTA and the future FTAA. On the basis of these results, the authors test the factors explaining the variation in exports in those two years to four types of markets -the domestic market, MERCOSUR, North America and the future FTAA- and conclude that the firms which registered rapid growth in their sales did so by channeling them preferentially to those regions; according to their study, the greater the weight of external trade compared with the income of a firm, the greater the probability that that firm will direct a growing share of its exports to its country of origin. These authors also note that foreign-owned firms also acquire a considerable part of their imports in the country of origin of their capital, although they do not specify the model for explaining this.

The evidence assembled in Baumann and Carneiro (2002) would appear to indicate that an evaluation of the effects of regional accords based exclusively on considerations of trade diversion and creation would be distorted because it does not take account of the influence of transnational corporations on trade flows. The summary made by Castilho (2002) of several studies which seek to analyze the possible effects of FTAA and the MERCOSUR-European Union agreement shows that in spite of the variety of methodologies used, none of these studies takes account of the weight of transnationals and intra-firm trade.

Finally, mention must be made of the study by Coutinho and others (2003), which, although it does not explicitly analyze the influence of foreign-owned firms on regional trade patterns, but rather the competitive situation and prospects of a set of production chains vis-à-vis the new rounds of negotiations on FTAA and the MERCOSUR-European Union agreement, does take into account, in its analysis and summarized results, the importance of the strategies adopted by transnational corporations. According to this 
study, the positive effects of integration agreements on production chains where the subsidiaries of transnational corporations are the leading players would be conditional upon the possibility of those subsidiaries becoming better export platforms than other subsidiaries of the firm or the parent firm itself.

\section{IV}

\section{The geographical orientation of the foreign trade of subsidiaries of foreign-owned firms in Brazil}

\section{General characteristics of the sample}

As the differences between domestic and foreignowned firms in terms of volume of trade were already noted in a number of studies, this section will seek to identify and classify those differences according to regions of origin and destination of foreign trade. The question we must answer here is whether, in this respect, the trade pattern of foreign-owned firms is different from that of domestic ones, and whether, in the case of foreign-owned firms, their region of origin carries much weight in determining their pattern of trade with the different regions.

In order to find the answer to this, we used foreign trade data for 80 domestic and 85 foreign-owned firms in 1989, 1997 and 2000. All the firms are among the 500 biggest firms in Brazil and were selected for having maintained this status in all three of the years in question. Of the foreign-owned firms, 33 are from the United States and Canada, 42 from the European Union, 7 from Asia, and 3 from other areas of the world.

The available data include the volume of imports and exports by region of destination and origin, sales turnover, and sector of activity of each firm. ${ }^{2}$ All the variables are expressed in U.S. dollars at 2000 prices, deflated by the United States Wholesale Price Index.

The firms included in the panel represent nearly $30 \%$ of the total sales of the industrial sector and almost $30 \%$ of the exports and over $20 \%$ of the total

2 The sector of activity is defined according to the National Classification of Economic Activities (CNAE) at the two-digit level, taking the most representative product in the firm's overall sales. imports of the country in the period studied. ${ }^{3}$ Consequently, although the sample is relatively small, it is highly representative, so that some of the conclusions of this analysis can be extrapolated to industry as a whole.

The data given in table 3 on the nationality of the firms and the volume of their trade by the destination of their exports and the origin of their imports allow us to obtain a first approximation of their regional trade pattern. The Latin American market does not seem to be very important for the domestic firms, especially in terms of exports, since only less than $10 \%$ of their exports go to it. The situation changes in the case of imports, however, since a major percentage of the external purchases of those firms come from the ALADI countries. The rest of their trade is fairly well distributed among the NAFTA countries, the European Union and the rest of the world, the first two of these destinations being the most important.

The exports of firms from NAFTA and the European Union, for their part, go mainly to their markets of origin and to Latin America, especially MERCOSUR. In 1989 this was not an important market for those firms, but the situation changed in the 1990s with the deepening of the bonds between the member countries. However, although they are still significant, the coefficients of exports to MERCOSUR went down markedly between 1997 and 2000 as a result of the exchange rate mismatches caused by the devaluation of the Brazilian real early in 1999 and the subsequent crisis in Argentina. The data clearly show

\footnotetext{
3 The total value of industrial sales was obtained from the annual industrial surveys of the Brazilian Geographical and Statistical Institute (IBGE), which makes a census of the industrial firms (manufacturing and mineral extraction) with over 30 employees. Firms with fewer than 30 employees are covered in the sample. The sales of the firms in the panel are gross sales, whereas the sales
} 
the importance of the markets of origin in the imports of the subsidiaries of European and NAFTA-based firms, which is much greater than in the case of exports.

The Asian firms are those which are most closely integrated with their countries of origin, both in terms of imports and exports. Asia is the origin and destination of over half the foreign trade of those firms. Figure 1 gives data on the average values for the three years studied, which clearly illustrate these conclusions.

Although the results are quite clear, a more precise analysis of this trade pattern can be made through an econometric model which isolates the possible influence of a firm's sector of activity and size on the origin and destination of its foreign trade.

\begin{tabular}{|c|c|c|c|c|c|c|c|c|c|c|c|c|c|}
\hline \multirow{3}{*}{ Origin of capital } & \multirow{3}{*}{ Year } & \multicolumn{11}{|c|}{$\begin{array}{l}\text { Brazil: External trade of selected firms as a proportion of total external trade } \\
\text { of the country, by origin of capital and region of origin or destination of imports } \\
\text { and exports, 1989, } 1997 \text { and } 2000 \\
\text { (Percentages) }\end{array}$} & \multirow[b]{3}{*}{$\begin{array}{c}\text { Rest } \\
\text { of } \\
\text { world }\end{array}$} \\
\hline & & \multicolumn{6}{|c|}{ Exports, by destination } & \multicolumn{5}{|c|}{ Imports, by origin } & \\
\hline & & MERC & NAFTA & ALADI & $\mathrm{EU}$ & Asia & $\begin{array}{l}\text { Rest } \\
\text { of } \\
\text { world }\end{array}$ & MERC & NAFTA & ALADI & EU & Asia & \\
\hline \multirow[t]{3}{*}{ Brazil } & 1989 & 3 & 21 & 1 & 29 & 33 & 13 & 8 & 38 & 13 & 21 & 9 & 11 \\
\hline & 1997 & 9 & 19 & 3 & 25 & 26 & 16 & 7 & 33 & 12 & 21 & 15 & 12 \\
\hline & 2000 & 6 & 30 & 2 & 30 & 17 & 14 & 9 & 40 & 11 & 23 & 9 & 8 \\
\hline \multirow[t]{3}{*}{ NAFTA } & 1989 & 4 & 39 & 8 & 25 & 14 & 10 & 4 & 66 & 2 & 16 & 11 & 1 \\
\hline & 1997 & 32 & 23 & 12 & 15 & 8 & 9 & 6 & 47 & 1 & 26 & 11 & 9 \\
\hline & 2000 & 25 & 21 & 13 & 23 & 8 & 11 & 21 & 49 & 1 & 19 & 6 & 4 \\
\hline \multirow[t]{3}{*}{ European Union } & 1989 & 5 & 28 & 8 & 47 & 4 & 8 & 11 & 17 & 3 & 66 & 2 & 2 \\
\hline & 1997 & 32 & 14 & 14 & 22 & 8 & 10 & 20 & 11 & 2 & 49 & 7 & 11 \\
\hline & 2000 & 19 & 31 & 10 & 28 & 4 & 9 & 15 & 19 & 0 & 54 & 10 & 2 \\
\hline \multirow[t]{3}{*}{ Asia } & 1989 & 1 & 11 & 3 & 15 & 66 & 4 & 3 & 17 & 0 & 8 & 72 & 0 \\
\hline & 1997 & 10 & 11 & 9 & 15 & 54 & 1 & 2 & 22 & 0 & 3 & 72 & 2 \\
\hline & 2000 & 5 & 21 & 3 & 20 & 50 & 1 & 3 & 19 & 0 & 6 & 70 & 1 \\
\hline \multirow[t]{3}{*}{ Rest of world } & 1989 & 8 & 4 & 1 & 66 & 10 & 11 & 0 & 59 & 2 & 7 & 1 & 32 \\
\hline & 1997 & 18 & 7 & 1 & 30 & 14 & 30 & 0 & 66 & 6 & 14 & 0 & 13 \\
\hline & 2000 & 11 & 4 & 4 & 28 & 27 & 26 & 2 & 74 & 1 & 17 & 1 & 5 \\
\hline
\end{tabular}

Source: Prepared by the authors on the basis of data from the Ministry of Foreign Trade (SECEX).

THE INFLUENCE OF CAPITAL ORIGIN ON BRAZILIAN FOREIGN TRADE PATTERNS • CÉLIO HIRATUKA AND FERNANDA DE NEGRI 

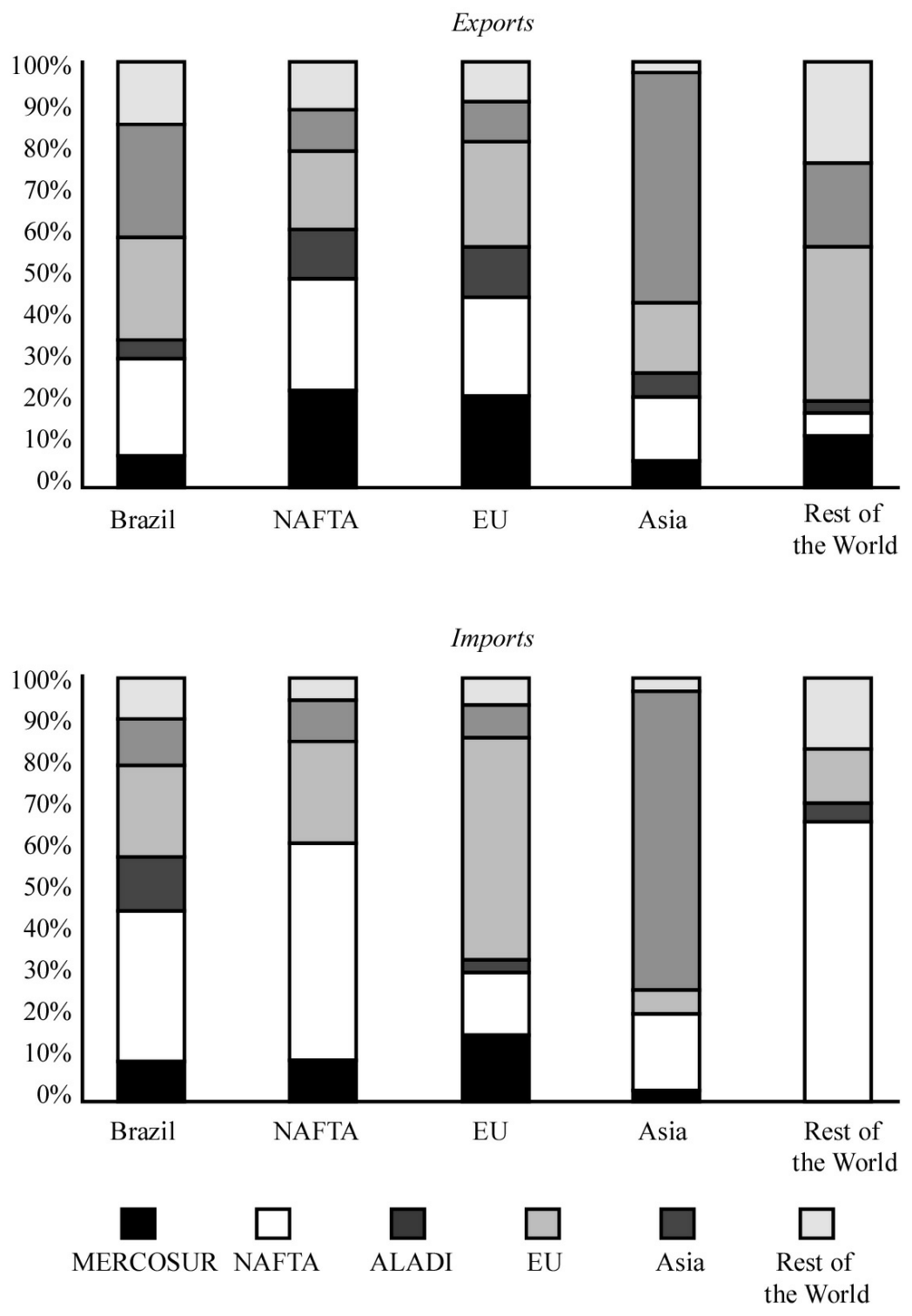

\section{Econometric procedures}

The sample used is a panel of various firms with data for three years. This format requires a different type of econometric model from the traditional cross-sectional regression models. As in a cross-sectional model, the panel model captures the specific effects on individuals, but unlike that model it can also capture timespecific dynamic effects. One of the advantages of the model used over cross-sectional analysis is the possibility of taking account of the heterogeneity that exists among individuals through the estimation of individual effects, thus separating the effects of the explana-

THE INFLUENCE OF CAPITAL ORIGIN ON BRAZILIAN FOREIGN TRADE PATTERNS • CÉLIO HIRATUKA AND FERNANDA DE NEGRI 
tory variables for individual effects not measured by the econometrist. ${ }^{4}$ This is because the model can capture dynamic aspects relating to each of the explanatory variables. In other words, it is possible to see the influence that the alteration of a given parameter has on the dependent variable, free of individual influences not captured by the other parameters of the regression.

With regard to the panel analysis, two possible estimation strategies may be noted: that using fixed effects models, and that using random effects models. In the first case, the individual effects can be freely correlated with the other regressors, whereas in random effects models it is assumed that there is no correlation between the individual effects and the other explanatory variables. In the fixed effects model, the ordinary least squares (OLS) estimator is consistent and efficient. Estimation with the random effects model, in turn, would require the use of generalized least squares, since it is assumed that the differences between individuals are distributed randomly.

In the specific case of the present study, it was decided to use the random effects model, since there are no changes in the region of origin of the firms in the period studied. The fixed effects model would only capture the dynamic effects of the panel, that is to say, the effects of change of nationality of the firms on their trade pattern. As in this sample there are no changes in the origin of the firms' capital, which is the subject of the study, it would not be appropriate to use the fixed effects model. Furthermore, in all the estimates Hausman's Test showed the desirability of using the random effects model. ${ }^{5}$

Using these models, the aim is to establish whether the country of origin of the firm is an important factor in its trade with the various economic blocs, especially NAFTA, the European Union and ALADI. These regions were chosen mainly because they would be the ones most affected by the regional accords that Brazil is currently negotiating. ${ }^{6}$ It is also important to

4 For greater details, see Baltagi (1995) and Hsiao (1986).

5 Hausman's Test is used in the analysis of the random effects model to verify the possible existence of a correlation between the individual effects and the explanatory variables. If no such correlation exists, then the random effects model is consistent and efficient. The Hausman's Test statistic has an $x^{2}$ distribution, on the null hypothesis that there is no correlation between the regressors and the individual effects.

6 More general models were also analyzed, whose dependent variables were the value of the firm's exports and imports. In this model, unlike the findings of other studies, no difference was found between domestic and foreign-owned firms as regards trade bear in mind the large share of the Brazilian industrial structure occupied by firms from the NAFTA and European Union countries. ${ }^{7}$ For its part, ALADI receives a considerable proportion of the exports of foreign-owned firms located in Brazil, as noted by Laplane and others (2001). In order to make this estimate, we took into account the size of each firm, its sector of activity, the technological content of the goods traded, and the current changes in the Brazilian economy in each of the years studied. The equations thus estimated are as follows: ${ }^{8}$

$$
\begin{aligned}
& l x \_r e g_{i t}=l f a t_{i t}+l i t \_x_{i t}+T L C_{i}+u e_{i}+a s i a_{i}+ \\
& \mathrm{rm}_{i}+\text { sector }_{i}+\text { year }_{i} \quad \text { [1] } \\
& l m_{-} r e g_{i t}=l_{f a t}+l i t \_m_{i t}+T L C_{i}+u e_{i}+a s i a_{i}+ \\
& \mathrm{rm}_{i}+\text { sector }_{i}+\text { year }_{i}
\end{aligned}
$$

where:

1) $l x \_r e g_{i t}$ is the logarithm of the exports of firm i to a given region in year $t$.

2) lm_reg $g_{i t}$ is the logarithm of the imports of firm $\mathrm{i}$ from a given region in year $t$.

3) f $_{\text {f }}{ }_{i t}$ is the sales turnover of firm $\mathrm{i}$ in year $t$. The value of the coefficient corresponds to the elasticity of the firm's exports or imports in relation to its size, represented here by its sales turnover. This is a way of taking account of the influence of the size of firms on their external trade.

4) lit_ $x_{i t}$ and $l i t \_m_{i t}$ express the logarithm of variables that seek to capture the degree of technological content in the firm's exports and imports. In order to construct this variable, a weighted average was made of the percentage share of each category of technological density in the total trade of the firms, as follows:

$$
\begin{aligned}
& i t \_x_{i t}=\left(p r i m \_x_{i t} x 1\right)+\left(r n \_x x_{i t} x 2\right)+\left(b i t \_x_{i t} x 3\right) \\
& +\left(m i t \_x_{i t} x 4\right)+\left(a i t x_{i t} x 5\right) \\
& i t \_m_{i t}=\left(p r i m \_m_{i t} x 1\right)+\left(r n \_m_{i t} x 2\right)+\left(b i t \_m_{i t} x 3\right) \\
& +\left(\text { mit_m } m_{i t} x 4\right)+\left(a i t \_m_{i t} x 5\right)
\end{aligned}
$$

where prim_ $x_{i t}$ is the proportion of primary commodities in the total exports of firm i, rn_ $x_{i t}$ is the proportion of products with intensive use of

volume. This is very likely due to the size of the sample analyzed and the relative homogeneity of the firms involved.

7 In 2000 the European Union accounted for 46\% of total FDI flows into Brazil, which the figure for the NAFTA countries was $26 \%$.

8 The classification of the technological density of products is the same as that used by UNCTAD (2002a). 
natural resources, and bit_ $x_{i t}$, mit_ $x_{i t}$ and ait_ $x_{i t}$ respectively represent the proportions of products of low, medium and high technology. The same procedure was used to calculate the technological content of imports. The degree of technological content of trade is measured on a scale from 1 to 5 .

5) $T L C_{i}, u e_{i}$, asia $_{i}$ and $r m_{i}$ are binary variables that identify the origin of the capital of firm $i$ : NAFTA, the European Union (EU), Asia and the rest of the world. The coefficients of these variables indicate to what extent the behaviour of firms from each of these regions differs from that of domestic firms.

6) sector $_{i}$ represents a set of 12 binary variables designed to capture the differences between the 13 sectors making up the sample.

7) year $_{i}$ represents the two binary variables used to capture the differences between the years 1989, 1997 and 2000 which have affected the different firms in the same way. In this way, it is hoped to prevent the differences observed between domestic and foreign-owned firms and between foreignowned firms from different regions from being contaminated by conjunctural factors.

\section{Results of the estimates}

The results obtained from these estimates are given in table 4. As far as trade with Latin America is concerned, there are no significant differences between foreign-owned and domestic firms. ${ }^{9}$ European firms are an exception in this respect, since they tend to import more from Latin America than the others, but their coefficient is not very significant. This result seems to be in contradiction with the figures given in table 3, which suggest that the Latin American market played an important role in the exports of European and NAFTA firms. This apparent contradiction can be explained because the econometric exercise was based on individualized data for the firms, such as size and sector. Thus, the aggregate data in table 3 may not

\footnotetext{
9 As is customary when using binary variables in the regression model, the dummy variable distinguishing domestic firms was left out of the equation so that the coefficients of the other dummy variables for the region (NAFTA, the EU and Asia) can be interpreted in relation to it.
}

reflect a generalized form of behaviour on the part of all the firms. It should also be borne in mind that the coefficient of the model may be conditioned by the limited importance the Latin American market had for European and NAFTA firms in 1989. Furthermore, that table referred to the proportion of total exports of the firms to the different markets and to absolute volumes of trade. Indeed, it is in trade with the developed countries that the differences between foreign-owned and domestic firms are most significant, at least as far as imports are concerned.

With regard to trade with the NAFTA countries, there are no significant differences either between the two groups of firms as regards their exports to that region. The disparity in the volume of imports is quite marked, however. The regression coefficients indicate that firms from the United States, Canada and the rest of the world tend to import significantly larger volumes from NAFTA countries than domestic firms, as already suggested in table $3 .{ }^{10}$ It may be noted that this difference is not due to the sector of activity of the firms, as might be argued on the basis of the initial data, since this was one of the control variables inserted in the model. The coefficient of the dummy variable on the origin of the firms' capital indicates that NAFTA firms tend to register average import volumes which are over $3,000 \%$ higher than those of firms from other regions. ${ }^{11}$

The volume of exports to the European Union does not differ much either among firms which are of different nationalities but are of similar size, operate in the same sector, and market products of similar technological density. As in the previous case, however, imports from the European Union by European firms considerably exceed those of domestic firms (by $1,600 \%$ on average). Firms from the NAFTA countries also tend to import more from the European Union than domestic firms, although in this case the difference is not so marked. It was also observed that Asian firms tend to import less from the European Union than domestic firms and hence less than the subsidiaries of European firms. This is because of the high import coefficient of Asian firms from their region of origin (table 3 and figure 1 above).

\footnotetext{
10 were no Mexican firms in the sample.

${ }^{11}$ As the dependent variable is in logarithmic form but the dummy variable is not, this percentage can only be obtained through the following transform: $\left[10^{\beta}-1\right] \times 100$.
} 
TABLE 4

Brazil: Results of estimates of exports and imports of firms to and from specific regions ${ }^{a}$

\begin{tabular}{|c|c|c|c|c|}
\hline \multicolumn{5}{|c|}{ Latin Americab } \\
\hline \multirow[t]{2}{*}{ Variables } & \multicolumn{2}{|c|}{ Exports } & \multicolumn{2}{|c|}{ Imports } \\
\hline & Estimate & $\mathrm{t}$ test & Estimate & t test \\
\hline Intercept & -5.57 & $-7.24 *$ & -6.15 & $-4.80 *$ \\
\hline Lfat & 0.98 & $7.91 *$ & 1.14 & $6.24 *$ \\
\hline Lit & 0.16 & 0.59 & -0.52 & 1.14 \\
\hline NAFTA & 0.33 & 0.98 & 0.40 & 0.78 \\
\hline Rest of world & 0.93 & 1.10 & 0.19 & 0.13 \\
\hline Asia & 0.33 & 0.44 & -0.91 & -0.78 \\
\hline European Union & 0.42 & 1.25 & 0.98 & $1.83 * *$ \\
\hline Number of firms & & 144 & & 126 \\
\hline $\mathrm{R}^{2}$ & & 0.43 & & 0.26 \\
\hline Hausman $(\operatorname{Pr}>m)$ & & 0.25 & & 0.51 \\
\hline
\end{tabular}

North American Free Trade Agreement (NAFTA)

\begin{tabular}{|c|c|c|c|c|}
\hline \multirow[t]{2}{*}{ Variables } & \multicolumn{2}{|c|}{ Exports } & \multicolumn{2}{|c|}{ Imports } \\
\hline & Estimate & $\mathrm{t}$ test & Estimate & $\mathrm{t}$ test \\
\hline Intercept & -4.25 & $-3.85 *$ & -6.84 & $-8.68 *$ \\
\hline Lfat & 0.87 & $4.90 *$ & 1.17 & $9.74 *$ \\
\hline Lit & 0.91 & $1.85 * *$ & -0.20 & 1.03 \\
\hline NAFTA & -0.16 & -0.31 & 1.53 & $4.06^{*}$ \\
\hline Rest of world & 1.11 & 0.56 & 1.72 & $1.78 * *$ \\
\hline Asia & -0.01 & -0.01 & 0.004 & 0.01 \\
\hline European Union & -0.41 & -0.82 & 0.07 & 0.20 \\
\hline Number of firms & & 125 & & 154 \\
\hline $\mathrm{R}^{2}$ & & 0.19 & & 0.38 \\
\hline Hausman $(\operatorname{Pr}>\mathrm{m}$ & & 0.09 & & 0.12 \\
\hline
\end{tabular}

\begin{tabular}{|c|c|c|c|c|}
\hline \multicolumn{5}{|c|}{ European Union } \\
\hline \multirow[t]{2}{*}{ Variables } & \multicolumn{2}{|c|}{ Exports } & \multicolumn{2}{|c|}{ Imports } \\
\hline & Estimate & $\mathrm{t}$ test & Estimate & $\mathrm{t}$ test \\
\hline Intercept & -0.97 & -0.75 & -6.58 & $-9.86^{*}$ \\
\hline Lfat & 0.56 & $2.72 *$ & 1.09 & $10.69^{*}$ \\
\hline Lit & 0.31 & 0.75 & 0.45 & $2.75^{*}$ \\
\hline NAFTA & -0.39 & -0.64 & 0.57 & $1.83 * *$ \\
\hline Rest of world & 0.82 & 0.46 & -0.01 & -0.01 \\
\hline Asia & -1.28 & -0.90 & -1.07 & $-1.75 * *$ \\
\hline European Union & 0.54 & 0.89 & 1.23 & $4.09 *$ \\
\hline Number of firms & & 135 & & 154 \\
\hline $\mathrm{R}^{2}$ & & 0.11 & & 0.40 \\
\hline Hausman $(\operatorname{Pr}>m)$ & & 0.31 & & 0.99 \\
\hline
\end{tabular}

Source: Prepared by the authors.

a $*$ variable significant at $5 \%$. ** variable significant at $10 \%$.

b MERCOSUR and ALADI, except Mexico.
In general terms, these results indicate a different trade pattern between domestic and foreign-owned firms and also among the foreign-owned firms themselves. There would appear to be a very strong link between the subsidiaries of foreign-owned firms and their regions of origin in the case of imports, possibly due to intra-firm trade by the subsidiaries in Brazil with their parent firms. This is not the case with Brazilian exports to those countries, however, since there was no observed tendency for such subsidiaries to export to their respective regions of origin.

According to Laplane and Sarti (2002) and Hiratuka (2002), these results may be interpreted as a consequence of the internationalization strategies of the Brazilian subsidiaries of foreign firms or even of the form of insertion of those subsidiaries in the global strategies of their parent firms. The main aim of this insertion is to serve the local market and the adjoining region, without playing an important role as suppliers of more developed regions. This characteristic, which is shared by both the NAFTA and European Union firms, results in a lopsided pattern of integration with their regions of origin which is much more marked in the case of imports than in that of exports.

One of the aims of the present study is to determine whether the technological density of the trade of domestic and foreign-owned firms is one of the factors explaining the above-mentioned imbalance in the trade flows with the regions of origin. This aim is justified by the tendency of the transnational corporations to internalize the production of technology-intensive goods, as highlighted in a number of theoretical studies on the subject. ${ }^{12}$ Filipe, Fontoura and Saucier (2002) analyzed the intra-firm trade patterns of United States transnational corporations and confirmed that technological density is a determining factor in intrafirm trade. Thus, such trade is bound to have a greater content of technology than trade with independent firms. This matter will be addressed in greater depth in the following section, through an analysis of the foreign-owned firms included in the panel.

${ }^{12}$ See for example Casson and Pearce (1993).

THE INFLUENCE OF CAPITAL ORIGIN ON BRAZILIAN FOREIGN TRADE PATTERNS - CÉLIO HIRATUKA AND FERNANDA DE NEGRI 
$\mathrm{V}$

\section{The influence of the technological density of products on the trade patterns of foreign-owned firms in Brazil}

It was seen in the previous section that European and United States firms have a greater tendency to import from their regions of origin than firms of other nationalities. Much of the trade with the region of origin probably takes place between the subsidiary and its parent firm: i.e., the channel used by the Brazilian subsidiary to trade with its country of origin is the parent firm. For this reason, and because of the lack of specific data on intra-firm trade in Brazil, trade with the country of origin is often used as a proxy variable for intra-firm trade (Baumann, 1993).

The determining factors of intra-firm trade may be different from those determining the overall trade of firms. Intra-firm trade may be due to specific strategies of each firm, to sectoral aspects, or - and this is what we seek to determine in this section - to the technological content of the products traded.

In order to evaluate the extent to which the technological content influences the trade of a foreignowned firm with its region of origin, equations on exports and imports to and from that region were analyzed. As in the previous section, the methodology used was panel data analysis. Domestic firms, and those from the "rest of the world" were removed from the initial sample, leaving only the Asian, European and NAFTA firms. The equations used were as follows:

$$
l x_{-} r o_{i t}=l f a t_{i t}+l i t_{-} x_{i t}+T L C_{i}+a s i a_{i}+
$$
sector $_{i}+$ year $_{i}[5]$

$$
\begin{aligned}
& l m_{-} r o_{i t}=\text { lfat }_{i t} \\
& \text { sector }_{i}+\text { year }_{i}[6]
\end{aligned}
$$

where $l x \_r o_{i t}$ and $l m \_r o_{i t}$ are the exports and imports of firm i to its region of origin in year $t$, in logarithmic form. The other variables are the same as those given in section IV. 2 above. ${ }^{13}$ The results obtained are given in table 5 .

\footnotetext{
13 In this case, the dummy variable distinguishing the European firms was left out of the equation in order for the coefficients of the

\begin{tabular}{|c|c|c|c|c|}
\hline \multirow{3}{*}{ Variables } & \multicolumn{4}{|c|}{$\begin{array}{l}\text { Brazil: Results of estimated exports and } \\
\text { imports of foreign-owned firms to and from } \\
\text { their respective regions of origin }\end{array}$} \\
\hline & \multicolumn{2}{|c|}{ Exports } & \multicolumn{2}{|c|}{ Imports } \\
\hline & Estimate & $\mathrm{t}$ test & Estimate & $\mathrm{t}$ test \\
\hline Intercept & 0,10 & 0,05 & $-7,16$ & $-7,85^{*}$ \\
\hline Lfat & 0,73 & $2,63^{*}$ & 1,01 & $8,05^{*}$ \\
\hline Lit & $-0,04$ & $-0,08$ & 0,93 & $3,85^{*}$ \\
\hline NAFTA & 0,46 & 0,71 & 0,10 & 0,30 \\
\hline Asia & 1,93 & 1,51 & 0,02 & 0,03 \\
\hline \multicolumn{2}{|c|}{ Number of firms } & \multicolumn{2}{|l|}{72} & 81 \\
\hline \multicolumn{2}{|c|}{$\mathrm{R}^{2}$} & \multicolumn{2}{|l|}{0,18} & 0,52 \\
\hline \multicolumn{2}{|c|}{ Hausman $(\operatorname{Pr}>m)$} & 0,41 & & 0,99 \\
\hline
\end{tabular}
other dummy variables for the region (NAFTA and Asia) to be interpreted in relation to it.
}

a Variable significant at 5\%.

The first important result concerns the coefficients of the dummy variables indicating the origin of the firms' capital. These show that there are no substantial differences among the transnational firms of different nationalities as regards trade with their respective countries of origin. The volume of intrafirm trade of the NAFTA firms, for example, is quite similar to that of the European firms, which are the basis for comparison in the model, and the Asian ones.

With regard to the technological density of the intra-firm trade of the transnational corporations, the results show that as the technological content of the imports of these firms rises, there is a corresponding rise in their imports from their region of origin. For every increase of one percentage point in the indicator of technological density of the products imported by the firm, the volume of imports from its region of origin rises by $0.93 \%$. In the case of exports to the region of origin, in contrast, the technological density is not statistically significant. It should be borne in mind that these results are not affected by the firm's sector of activity, since this is one of the control variables inserted in the model.

It may therefore be concluded that the technological density of the imports by transnational firms from their region of origin is greater than that of their total 
imports, which may be explained by the greater propensity of the firms to import from their own regions, as shown in the previous section. In other words, the greater volume of imports from their region of origin may be due to the technological dependence of the subsidiaries of foreign firms on their parent firms, bearing in mind the previously explained relationship between trade with the region of origin and intra-firm trade.

This result may be due to the tendency of the transnational corporations to internalize more technology-intensive production rather than trading it freely on the market. Such internalization prevents new technologies developed by the corporations from being readily imitated by competitors. In the specific case of

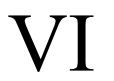

\section{Final Remarks}

According to the Census of Foreign Capital made by the Central Bank of Brazil, foreign-owned firms made $60 \%$ of the exports and $56 \%$ of the country's imports in the year 2000. As the intra-firm trade of those firms accounted for $63 \%$ of their exports and $57 \%$ of their imports, it may be concluded that almost $38 \%$ of Brazil's total exports and $33 \%$ of its total imports corresponded to intra-firm trade.

It is therefore extremely important to determine the effects of the activities of foreign-owned firms on Brazil's foreign trade. As noted in section III, a number of studies have pointed out the differences between the trade behaviour of foreign-owned firms and that of domestic firms, emphasizing that the disparities are much more marked in imports than in exports.

The present study represents an important contribution in this field, since the results of the model support the hypothesis that intra-firm trade is one of the factors explaining the differences in behaviour between domestic and foreign-owned firms. In our view, the fact that firms belonging to the United States, Canada and Europe import more products from their regions of origin than other firms, while not displaying any significant differences from them in terms of the regions of destination of their exports, reflects the position that the Brazilian subsidiaries of foreign
Brazil, the imbalance between exports and imports may be related with the role played by the Brazilian subsidiaries of transnational corporations within the overall operations of the parent firm. According to Laplane and Sarti (1997 and 1999), the main attraction of the country for foreign investment is the exploitation of the domestic and regional markets. Accordingly, the subsidiaries in Brazil are mostly not authorized to act as global suppliers of the transnational corporation but form part of its world network, acquiring intermediate or final products with a higher technological content from the parent firm or its subsidiaries in developed countries, as noted by Laplane and others (2001) and Hiratuka (2002).

corporations occupy in the global strategies of their parent firms.

In a world context in which the transnational corporations are seeking to reorganize their production networks in order to maximize the results of their global operations as a whole, the role of their subsidiaries in Brazil seems to be more important in terms of access to the local market than as a link in the global supply network for other regions, especially when the technological content of the products traded is taken into account.

Two important inferences may be drawn from these conclusions. The first concerns competitiveness and foreign trade policies. Many developing countries have striven to apply active policies to attract investments, while at the same time seeking to improve the contribution of transnational firms to foreign trade and industrial development (UNCTAD, 2002b). Such policies are based on a recognition that the investment and plant location decisions of the great transnational corporations have increasingly strong effects on trade flows. This is a fact which must be taken into account when drafting policies on FDI or trade policies aimed at sectors where those corporations predominate. In the case of Brazil, a deeper knowledge must be gained of the factors conditioning the use of internal trade networks by the big corporations, in order to 
determine to what extent those factors can be the subject of public policies designed to increase the positive effects on exports.

The second inference concerns the simultaneous trade negotiations which are taking place on the FTAA and the accord between MERCOSUR and the European Union. As Baumann and Carneiro (2002) and Coutinho and others (2003) observed, the studies being made to evaluate the effects of regional agreements are limited because they do not take account of the effects of intra-firm trade or the strategies of the transnational corporations. They must therefore be complemented with studies which recognize that an important part of the trade with those regions does not follow the traditional trading pattern because it is no longer carried out between independent firms.

This means that the agreements must be analyzed not only as a function of their immediate effects on trade flows but also their impact on the foreign investments to be made by new firms or firms which are already installed in the country. In other words, the regional agreements can have important effects on the activities of the Brazilian subsidiaries of foreign firms and their insertion within the organizational structure of the parent firms, and these effects will undoubtedly be reflected in the trade flows.

Thus, for example, the tariff reductions within the framework of regional preference agreements could lead to a decision to replace production within the country with exports to the local market from the region of origin of the parent firm or from subsidiaries located in other countries covered by the agreement, thus further strengthening the inflow of intra-firm imports. It is also possible that part of the exports from Brazil to other countries forming part of the agreements will be replaced with exports from other places where the parent firm has subsidiaries. It may also be that the trade preferences will strengthen the position of subsidiaries located in Brazil through better utilization of the transnational firms' own channels to serve the closest outside markets.

These aspects highlight the importance of gaining a better understanding of the way in which the investments of transnational firms influence trade flows, especially in Brazil, where those firms are the leaders in various industrial branches. We hope that the present study will help to obtain a fuller understanding of some of these issues and will stimulate new studies in the same direction.

(Original: Portuguese)

\section{Bibliography}

Anderson, T. and T. Fredriksson (2000): Distinction between intermediate and finished products in intra-firm trade, International Journal of Industrial Organization, vol. 18, No. 5, Amsterdam, Elsevier Science.

Baltagi, B.H. (1995): Econometric Analysis of Panel Data, London, John Wiley \& Sons Ltd.

Baumann, R. (1993): Uma avaliação das exportações intrafirma do Brasil: 1980 e 1990, Pesquisa e planejamento econômico, vol. 23, No. 3, Brasilia, Institute of Applied Economic Research (IPEA), December.

Baumann, R. and F.G. Carneiro (2002): Behaviour of Brazilian export firms: implications for the Free Trade Area of the Americas, CEPAL Review, No. 78, LC/G.2187-P, Santiago, Chile, December.

Brainard, L. (1993): An empirical assessment of the proximity-concentration trade-off between multinational sales and trade, American Economic Review, vol. 87, No. 4, Nashville, Tennessee, American Economic Association.

Casson, M.C. and R.D. Pearce (1993): Intra-firm trade and developing countries, in H.P. Gray (ed.), Transnational Corporations and International Trade and Payments, London, The United Nations Library on Transnational Corporations.

Castilho, M. (2002): Impactos de acordos comerciais sobre a economia brasileira: resenho dos trabalhos recentes, Texto para discussão, No. 936, Brasilia, Institute of Applied Economic Research (IPEA).

Chesnais, F. (1996): A mundialização do capital, São Paulo, Xamã. Chudnovsky, D. and A. López (coords.) (2002): Integración regional e inversión extranjera directa: el caso del MERCOSUR, Buenos Aires, Inter-American Development Bank (IDB)/Institute for the Integration of Latin America and the Caribbean (INTAL).

Coutinho, L. and others (2003): Estudo da competitividade de cadeias integradas no Brasil: impacto das zonas de livre comércio (http://www.eco.unicamp.br/projetos/ neit/neitpesq.html).

De Negri, F. (2003): Desempenho comercial das empresas estrangeiras no Brasil na década de 90, Master's Thesis, Campinas, Institute of Economics, State University at Campinas (UNICAMP).

Dunning, J. (1993): Multinational Enterprises and the Global Economy, Reading, Addison-Wesley Publishers.

Filipe, J.P., A.P. Fontoura and P. Saucier (2002): US Intrafirm Trade: Sectoral, Country and Locational Determinants in the 90s, Working Paper, No. 2002/7, Lisbon, Universidade Técnica de Lisboa.

Helpman, H. (1984): A simple theory of trade with multinational corporation, Journal of Political Economy, No. 92, Chicago, The University of Chicago Press, June. 
Helpman, H. and P. Krugman (1985): Market Structure and International Trade, Cambridge, Massachusetts, The MIT Press.

Hiratuka, C. (2002): Empresas transnacionais e comércio exterior: uma análise das estratégias das filiais brasileiras no contexto de abertura econômica, Doctoral Thesis, Campinas, Institute of Economics, State University at Campinas (UNICAMP).

Hsiao, C. (1986): Analysis of Panel Data, London, Cambridge University Press.

Laplane, M.F and others (2001): La inversión extranjera directa en el MERCOSUR. El caso brasileño, in D. Chudnovsky (org.), El boom de inversión extranjera directa en el MERCOSUR, Madrid, Siglo Veintiuno.

Laplane, M.F. and F. Sarti (1997): Investimento direto estrangeiro e a retomada do crescimento sustentado nos anos 90, Economia $e$ sociedade, No. 8, Campinas, Institute of Economics, State University at Campinas (UNICAMP).

(1999): Investimento direto estrangeiro e o impacto na balança comercial nos anos 90, Texto para discussão, No. 629, Brasilia, Institute of Applied Economic Research (IPEA).

(2002): O investimento direto estrangeiro e a internacionalização da economia brasileira nos anos 90, Economia $e$ sociedade, No. 18, Campinas, Institute of Economics, State University at Campinas (UNICAMP).

Lipsey, R. (1998): Internationalized Production in Developed and Developing Countries and in Industry Sectors, NBER Working Paper, No. 6,405, Cambridge, Massachusetts, National Bureau of Economic Research.

Markusen, J. (1995): The boundaries of multinational enterprise and the theory of international trade, Journal of Economic Perspectives, vol. 9, No. 2, Nashville, Tennessee, American Economic Association.
Markusen, J. and A. Venables (1998): Multinational firms and the New Trade Theory, Journal of International Economics, No. 46, Madison, Wisconsin, University of Wisconsin.

Moreira, M.M. (1999): Estrangeiros em uma economia aberta: impactos recentes sobre produtividade, concentração e comércio exterior, in F. Giambiagi and M.M. Moreira (orgs.), A economia brasileira nos anos 90, Rio de Janeiro, Banco Nacional de Desenvolvimento Econômico e Social (BNDES).

Mortimore, M., S. Vergara and J. Katz (2001): La competitividad internacional en el desarrollo nacional: implicancias para la política de inversión extranjera directa (IED) en la América Latina, "Desarrollo productivo" series, No. 107, LC/L.1586P, Santiago, Chile, ECLAC. United Nations publication, Sales No. S.01.II.G.130

Pinheiro, A.C. and M.M. Moreira (2000): O perfil dos exportadores brasileiros de manufaturados nos anos 90: quais as implicações de política?, Texto para discussão, No. 80, Rio de Janeiro, Banco Nacional de Desenvolvimento Econômico e Social (BNDES).

UNCTAD (United Nations Conference on Trade and Development) (1995): World Investment Report 1995. Transnational Corporations and Competitiveness, UNCTAD/DTCI/26, Geneva, United Nations. United Nations publication, Sales No. E.95.II.A.9.

(2002a): Trade and Development Report 2002. Developing Countries in World Trade, UNCTAD /TDR/2002, New York, United Nations. United Nations publication, Sales No. E.02.II.D.2.

(2002b): World Investment Report 2002: Transnational Corporations and Export Competiti-veness, UNCTAD/WIR/2002, New York, United Nations. United Nations publication, Sales No. E.02.II.D.4. 